\title{
TRADEMARK ACTIVITY AND THE MARKET PERFORMANCE OF U.S. COMMERCIAL BANKS
}

\author{
Carlos González-Pedraz ${ }^{1}$, Sergio Mayordomo² \\ ${ }^{1}$ Department of Business Administration, Universidad Carlos III de Madrid, \\ C/ Madrid 126, 28903 Getafe, Madrid, Spain \\ ${ }^{2}$ Department of Research and Statistics, Comisión Nacional del Mercado de Valores (CNMV), \\ C/ Miguel Ángel 11, 28010 Madrid, Spain \\ E-mails: 1cugonzal@emp.uc3m.es (correspondingauthor); ${ }^{2}$ smgomez@cnmv.es
}

Received 27 May 2011; accepted 15 November 2011

\begin{abstract}
This empirical paper analyzes the effect of trademark activity on the market value and performance of US commercial banks from two perspectives. First, a longterm perspective considers the effect of such activity on banks' Tobin's $q$. Second, with a short-term perspective, the authors analyze the effect of trademark activity on banks' abnormal returns. An older portfolio of trademarks diminishes the ratio of market value to firm assets, but this ratio can be improved in the long term by abandoning old trademarks. Portfolios of trademarks with wide diversification do not help increase Tobin's $q$. Furthermore, according to an event study, the creation of a trademark has a positive effect on cumulative abnormal returns compared with no event, whereas a cancellation event has a negative impact.
\end{abstract}

Keywords: intangible assets, trademarks, Tobin's $q$, abnormal returns, event studies.

Reference to this paper should be made as follows: González-Pedraz, C.; Mayordomo, S. 2012. Trademark activity and the market performance of U.S. commercial banks, Journal of Business Economics and Management 13(5): 931-950.

JEL Classification: M3, G21.

\section{Introduction}

Banks innovate and respond to customers' initiatives and needs by offering new products and services, yet few of these innovations are patentable. Rather they are quite easy for other banks to imitate or replicate. How then can innovative banks protect their innovations? According to Teece (1986), banks should control complementary assets, such as marketing or distribution channels. In reality, commercial banks are undertaking significant investments in marketing and advertising; in 1999, they spent $\$ 5.1$ billion on advertising and marketing, equal to an estimated $8.9 \%$ of their net income before taxes (Örs 2006). Furthermore, Örs (2006) reveals that advertising has a positive and economically significant impact on bank profitability and considers advertising an important element of bank competition that is linked to ownership of relevant portfolios of trademarks. A trademark - any sign that helps distinguish a product or service, whether 
a word, a figure, or an image - thus is closely related to advertising and the intangible value of the firm.

Marketing strategy is one more of the set of strategic tools that firms may use to generate cash flows. The value of the future cash flows will be reflected in the bank market value. Poor trademarks strategies or weak marketing campaigns could lead to poor sales performance of the firm services. Given that the shareholder wealth can be viewed as the discounted value of expected cash flows, a revision of these expectations based on cancellation or introduction of trademarks could be manifested in the firm's stock price or even in a longer term bank performance.

In the retail banking sector, innovations also might relate to trademarks. In Rindova and Petkova's (2007) theoretical framework to explain the interaction of technological innovations with consumer perceptions, innovation enhances value creation but may not be perceived clearly by the demand side. Yet in retail banking, demand often changes before innovations appear. That is, customers' habits change first (e.g., Internet access), then banks introduce innovations to cope with these changes (e.g., online banking), which they also might trademark.

The study here investigates the link between trademark activity and the performance and the stock prices of U.S. commercial banks. The focus centers on the value added by trade- or service marks owned by the main U.S. commercial banks between 1996 and 2006, because trademarks can alter the market value of the firm, which in turn influences how investors perceive firm value. The study concentrates on commercial banks because, whether out of necessity (e.g., new segments of customers) or merit (e.g., new forms of competition), the financial sector has become an increasingly innovative industry.

Therefore, this paper estimates the impact of several explanatory variables related to banks' trademark activity on Tobin's $q$ (Tobin 1978). Tobin's $q$, that is, the ratio of the market valuation of financial claims relative to the cost of replacing the firm's assets has been used widely to assess profitable investment opportunities. The firms represent a set of assets and capabilities, such as knowledge, brand names, trade- and service marks, and other intangible factors, that get jointly valued on the market (see the seminal works of Grilliches (1981); Megna and Klock (1993); and the recent study of Krasnikov et al. (2009). This empirical study here focuses on the effect of specific characteristics of firm's trademark portfolio, such as age and scope, on firm's Tobin's $q$. Further implications about the firm's branding effort and readjustments of business strategies can be inferred at the light of the results.

Using quarterly data, the study here finds that an older portfolio of trademarks diminishes the ratio of market value to firm assets, though firms can improve this ratio by abandoning old trademarks. Also, trademarks with low ranges or application scopes add more value to the firm, in terms of a higher Tobin's $q$, than do trademarks with wide ranges. That is, specialization or specification in the trademark portfolio is preferable to diversification.

Finally, this paper also conducts a short-term analysis with a classical event study to investigate whether abnormal returns observed in banks depend on the banks' trade- 
mark activity. Using event study methodology (Campbell et al. 1997) we can analyze the impact of certain events related with trademark activity on the stock returns of a firm or set of firms. The event study developed in this study here relies on daily data and confirms that the abnormal returns attributable to trademark creation differ from the abnormal returns attributable to a trademark cancellation. Specifically, an introduction exerts a positive effect compared with no event, whereas a cancellation event has a negative impact in terms of cumulative abnormal returns. As the sample represents a period with a strong activity of mergers and acquisitions in the banking sector, the event study is carried out in dates which are free of potential mergers and acquisitions effects to avoid any trends in the data that could be confused with abnormal returns. This robustness test confirms the validity of the previous results.

By studying both the effect of trademark activity on firm value using quarterly data and the effect of introductions or cancellations of trademarks on abnormal stock returns, this work provides complementary analyses that offer results from both long- and short-term perspectives. The results therefore contribute to literature pertaining to trademark activity and commercial banking. The interesting implications regarding the effects of such activity on firm value should be of special interest for both investors and bank managers. For example, investors might infer bank value from its trademark policy, because certain events related to trademark activity have significant effects on firms' value in the short and long run. Accordingly, investors could go beyond the efficient market hypothesis, which asserts that they make trading decisions on the basis of the potential benefits of organizational initiatives announced by firms, and attend instead to the information revealed by the bank's trademarks policy. From a managerial perspective, these results suggest ways to manage trademark portfolios more efficiently and with lower expenditures, while distinguishing short- and long-run effects. Specifically, managers should try to maintain a young, dynamic portfolio of trademarks and prefer the introduction of focused trademarks but the cancellation of old, diversified ones.

To outline these findings, this article is organized as follows: Section 2 presents the theoretical framework, then, Section 3 contains the description of the data, the methodology, and the variables for the empirical study. The empirical results are described in Section 4. Finally, Section 5 concludes and discusses the implications for both investors and bank managers.

\section{Theoretical background}

Advertising and branding has been analyzed in terms of market value and performance in some studies in the intersection between management and economic literature. For example, the importance of advertising has been documented by Mathur and Mathur (1995) who find a significant increase in the firm market value after the announcement of an advertising slogan change. Also, Reilly et al. (1997) show that strategic marketing planning (i.e. promotion management decisions) influence the sales, profit, and stock market performance of firms. They find a positive relation between the level of advertising expenditures and shareholder wealth over an eight-year period. Hozier and Schatzberg (2000) find a significant decline in stock market values before announce- 
ments of advertising agency terminations and accounts placed in review (potential terminations). However, the authors do not find an improvement in firm performance following the agency termination of potential termination. Our study adds evidence to this interrelation and also examines the effect of marketing strategies focused on the banks' trademark activity on the performance and the stock prices.

Trademarks combine words, phrases, symbols, and designs to identify and distinguish the source of the goods or services. They also constitute important intangible assets of commercial banks. In their constant efforts to reach new segments of customers (e.g., immigrants, young people) and compete with electronic or savings banks, commercial banks have become very active and launched many trade- and service marks in recent years. Evidence of this importance can be found in Hasan et al. (2000) who investigate the impact of marketing on U.S. savings and loans industry and show a strong positive impact on the profitability of their non-interest business activities over the period 1985 and 1989. They also indicate that promotional expenditures of U.S. savings and loans increased due to the increased competition in the local markets as a result of the introduction of new competitors during the period.

As we have already introduced, this study first focuses on the value added by trade- or service marks by the main commercial banks of the United States between 1996 and 2006. To do so, this work estimates their impact on Tobin's $q$, a measure of performance traditionally employed in financial and managerial literature to explain a wide variety of phenomena. For example, the measure has helped estimate the relative importance of industry or share effects for determining the market value of firms (for a review, see Hall et al. 2007; see also Lindenberg, Ross 1981). In similar approaches to ours, other researches examine the impact of R\&D or patenting on firm performance or market value. Works such as those of Grilliches (1981), Megna and Klock (1993) and Hall (1993) also use Tobin's $q$ to estimate intangible assets such as intellectual capital and technological assets. Wernerfelt and Montgomery (1988) use this ratio as a measure of returns from diversification; finding that focused firms perform better than diversified ones. Simon and Sullivan (1993) apply Tobin's $q$ as a measure of brand equity in a similar way to our interpretation. Besides this latter study, in a related work, Krasnikov et al. (2009) analyze the financial impact of branding using trademarks for different industries.

Although Tobin's $q$ normally relates to non-financial firms where physical capital is a reasonable indicator of their value and ability to produce, there are some papers in previous literature that use the Tobin's $q$ to measure the performance of firms in the financial sector. For instance, Bharadwaj et al. (1999) use Tobin's $q$ to examine the association between Information Technology investments and firm value for a wide variety of industries including financial services. Salas and Saurina (2003) evaluate the effects of deregulation in the market power of Spanish banks, measured in terms of their Tobin's $q$ ratios. And recently, Greenhalgh and Rogers (2007) employ Tobin's $q$ to analyze the effect of trade and service marks in the market value of UK manufacturing and service sector firms, including the finance sector and other similar sectors in terms of physical capital. In contrast with the latter works, this empirical study here focuses on the effect of specific characteristics of firm's trademark portfolio, such as age and scope, on firm's 
market value. Further implications about the firm's branding effort and readjustments of business strategies can be inferred at the light of the results.

Rindova and Petkova (2007) note the importance of innovation for value creation, as well as the uncertainties associated with innovation on both supply and demand sides. Their focus is customers' and producers' adaptation to successful product innovation, such as through the creation of similarities between new products and existing ones to facilitate the use and spread of new technologies. However, there is not always a synchronized relation between technological innovation and product design; sometimes, an innovation emerges from external factors and changes the economy in general, as in the case of the widespread use of the Internet. As new technologies become more important and useful, new schemes for interpreting a new technology's value emerge and demand new product design. Existing products that are not appropriate for the new changes are abandoned. In the innovative bank sector for example, banks adapt their business lines to provide greater access to and promotion of banking services to more receptive customers who engage in a new kind of banking business.

Yet other managerial decisions also affect intangible assets, such as those related to product variety and diversification, and thus affect market value. The market environment and its interaction with the firm determine the success of a firm's strategies. For example, product variety might be an important strategic variable, because according to Sorenson (2000), the likely success of a firm's product portfolio increases as the number of products increases, though product line culling increases organizational efficiency when consumer preferences are stable. In the case of new technologies, consumer preferences should be clear, and the business strategy and trademark activity should reflect these developments closely. Thus, the ideal path might be clear, in which case culling seems necessary. In a comparable argument, Gambardella and Torrisi (1998) point out that a narrower trademark portfolio is beneficial, though other studies stress the importance of diversification (Siggelkow 2003) and show that broad product offerings can be a valuable strategy for firm managers. Li and Jin (2006) study the effect of diversification on firm returns in chemical and oil industries and find that diversified firms achieve higher returns than focused ones, though this finding may be specific to the industry context, in which the general products had low value prior to diversification. Thus, the key to determining the role of diversification is to test if such diversification is well valued by businesses or not.

This paper considers innovation and adaptation in terms of (1) the creation of trademarks, (2) the cancellation of trademarks, (3) the age of the stock of trademarks, and (4) the range of existing trademarks to study their effect on Tobin's $q$. That is, this paper analyzes the value that intangibles add to a firm, using quarterly data. In this sense, this approach undertakes a long-term analysis of the effect of trademark activity on banks' performance taking into account the theoretical framework detailed above.

In the second approach of this study, we turn our attention to banks' financial returns. A growing stream of literature also explores the impact of product innovation and advertising on financial returns and market value. R\&D expenditures and advertising expenditures have been previously found to be associated with firm specific advantage, 
which may result in increased firm value (see Branch 1974; Grabowski, Mueller 1978). Chaney et al. (1991) study the effects of new product introductions on the market value of firms with successful results (see also Koh, Venkatraman 1991; Agrawal, Kamamura 1995). Lane and Jacobson (1995) cite stock market reactions to brand extension announcements and estimate a model that links excess returns to brand attitude and brand name familiarity. Subramani and Walden (2001) investigate the impact of electronic commerce announcements on the market value of firms. Recently, Bayus et al. (2003) and Srinivasan et al. (2009) show that a firm's product releases and filed trademarks have a positive and significant impact on stock returns. Other works consider the potential spillover effects from a rival's innovation, such as when Fosfuri and Giarratana (2009) investigate the impact of rivals' product innovation and new advertising on a firm's financial market value in mature product markets.

In line with such research, this paper considers whether abnormal returns reflect banks' trademark activity. Like in Chaney et al. (1991) and Lane and Jacobson (1995), a classical event study and daily data are employed to analyze the effect of trademark activity; therefore, in contrast with the first empirical part, this second part adopts a short-term perspective in this case. The two analyses are complementary.

The efficient market hypothesis claims that investors incorporate all possible benefits of the organizational initiatives that firms announce into their decision making. If certain events related to trademark activity seem likely to increase (diminish) a firm's future cash flows, the stock market should respond positively (negatively), and the market value of the firm changes accordingly. Trademark activity could be the exemplar of such events for this type of studies. Trademark activity may reflect readjustment of business strategies and branding and could be considered as a proxy of investment and growth opportunities which should be derived in future cash flows. This information should be important in pricing equity securities and so, trademark activity news should affect to the firm value and the stock prices. This paper therefore defines two events: trademark introduction and trademark cancellation or extinction. An event study permits to determine if the creation and cancellation of trademarks leads to positive or negative abnormal returns in the short run.

\section{Data and methodology}

\subsection{Data}

The sample consists of the 16 most important commercial banks in the United States, according to the 2006 Fortune list: Capital One Financial, Regions Financial, WellsFargo, US Bancorp, Wachovia, State Street, JP Morgan Chase, BB\&T, Mellon Financial, Keycorp, Fifth Third Bancorp, Citibank, Bank of America, PNC Financial Services Group, Suntrust Banks, and National City. The market value and accounting data for each bank come from Compustat and Ecowin.

The information about the banks' trade- and service marks comes from the U.S. Patent Office (USPTO). Such trademarks protect intellectual property rights, and firms file them to secure legal protection of their brand names, recognizable designations, and 
symbols, as well as the firms' identities (e.g., Seethamraju 2003). The information extracted from the USPTO includes international and U.S. classes for each trademark, the mark draw, the filing date, and, if applicable, the cancellation date. Any single missing values in a series are filled by linear interpolation if information about previous and later observations is available or by the average growth rate if the gaps fall at one of extremes of the sample period. This interpolation procedure was used in very few cases. This procedure leads to a sample of 960 cancellations and 1560 introductions of trademarks by the 16 major U.S. commercial banks during the 11-year period from January 1996 to December 2006.

\subsection{Methodology}

This analysis uses two different approaches to study the effects of trademarks on stock market behavior for banks. First, this paper applies the classical Tobin's $q$ linear model, as is commonly used in prior literature. Second, with a more dynamic scope, this paper studies the effect of banks' trademark policies on performance, according to abnormal daily returns, using a classical event study.

\subsubsection{Linear model for Tobin's $q$}

\section{Dependent variable: Tobin's q}

The first empirical analysis entails the effects of trademarks on the Tobin's $q$ ratio, that is, the ratio of market value to tangible assets, which represents the added value of such assets for a given firm. The data source defines a bank's market value as the sum of market capitalization (close price multiplied by the quarterly common shares outstanding); tangible assets are the sum of gross fixed assets plus inventory stocks. Therefore, the Tobin's $q$ expression of firm $i$ is:

$$
q_{i} \equiv \frac{V_{i}}{A_{i}+K_{i}},
$$

where $V_{i}, A_{i}$, and $K_{i}$ represent the market value, the value of physical assets, and the value of intangible (knowledge) assets, respectively. In equilibrium, this value should equal one, because there are incentives to invest when shares can be sold for more than the cost of the underlying assets and incentives to disinvest when shares can be purchased for less than the assets. However, Tobin's $q$ defined in this way is difficult to observe, so instead, this study uses the replacement value of the firm's physical assets as the dependent variable; that is:

$$
\hat{q}_{i} \equiv \frac{V_{i}}{A_{i}} .
$$

In practice, this ratio excludes intangible assets from the denominator. The variable relates to firms' accounting features and their behavior with respect to trademark activity for the sample period.

\section{Independent variables of theoretical interest}

This study also uses the number of living trademarks in each period for each bank and per employee, denoted by Stock. This variable is a proxy measure of the innovation capacity of each firm. The stock of trademarks per employee provides a natural way to 
define the size of the portfolio of trademarks in each quarter, as balanced by the number of employees, which provides a good proxy for the size of the firm. Additionally, we include the square of the number of living trademarks to employee to allow for a nonlinear relation between the innovation capacity and the firm performance.

The age of the stock of trademarks is measured according to the filing date and the cancellation date. If the trademark has not been cancelled, we compute the age according to the last date in the sample, which makes this variable right censored. In practice, this variable enters in the model as the logarithm of the average age of the stock of living trademarks, measured in days, for each quarter $\left(\log \left(\overline{\text { Age }_{\text {live }}}\right)\right)$.

To modify stock age, bank's managers can discard trademarks of a certain age. In order to analyze this effect, the estimation procedure includes the logarithm of the average age of cancelled trademarks, measured in days, for each quarter $\left(\log \left(\overline{\text { Age }_{\text {cancel }}}\right)\right)$.

\section{Control variables}

The use of control variables, mostly derived from prior literature, greatly reduces the likelihood of finding spurious effects. For example, the use of the one-period lagged Tobin's $q$, denoted by Tobin's $q_{t-1}$, helps to control for autoregressive effects. The previous value of the Tobin's $q$ ratio clearly is relevant to the current value of Tobin's $q$.

The stock diversification of living trademarks in each quarter (Diversification) is the average number of different U.S. classes registered in each case. A diversified portfolio means the stock of living trademarks has a wide range, which implies a high value for this variable.

Size should have effects on market value behavior. The size is measured by means of the logarithm of equity book value. Large firms might systematically have larger portfolios of trademarks; furthermore, this variable is a common market value factor for firms in classic corporate finance literature. For the same reason, this analysis also includes the return over income (ROI) lagged two periods, which helps us to control for the performance that the firm has realized two periods before.

The value of e-commerce in the United States measures the amount of internet transactions and is given in USD although it is incorporated in the model in log terms. It is obtained from the U.S. Census Bureau. This variable provides a proxy for the use of the Internet and new technologies by customers. This measure also reflects changes in customers' habits. Therefore, the e-commerce variable helps us control for the interaction between trademark activity and changes in banks' activity due to increasing use of new technologies. That is, there is a large potential market for new online financial services and products that could be responsible for a systematic increase in trademarks oriented towards this new market.

To control by the fact that bank's performance measure could be determined by its financial health, we use the bank rating as an additional control variable. We define the rating related variable as a discrete variable with values ranging between 1 and 9 , such that 1 corresponds to rating $\mathrm{BB}+$ (the lowest rating in the sample) and 9 to rating $\mathrm{AA}$ (the highest rating in the sample). The rest of the values for the rating variable cor- 
respond to the intermediate ratings. We expect a positive effect of this variable which would reflect that firms with a better financial health exhibit a better performance.

The number of mergers and acquisitions (M\&A) during the sample period was remarkable. M\&A may introduce some trends in the data which could be confused with unexpected and significant changes in firm's performance as well as with abnormal returns. Besides the effects on firm's performance, M\&A may create brand problems which could affect the trademark activity. For instance, after a given merger or acquisition the involved banks would need to decide what to do with overlapping and competing product brands. We try to isolate these effects from the ones shown by the trademarks related variables. For this reason, we control by the M\&A activity of every bank in the sample introducing as an additional explanatory variable the number of M\&A which were announced during a given quarter. The expected sign of this variable is not clear given that as Lubatkin (1983) state, inefficiencies associated to a merge may negate the possible benefits of merger and so, its overall effect is not significant.

As a summary, Table 1 reports the main descriptive statistics for all variables employed in this analysis, including the mean, standard deviation (Std. dev.), minimum (Min), maximum (Max), and number of observations $(N)$. The sample consists of quarterly data for sixteen banks over eleven year, that is, if there are no missing observations, $N$ is equal to 704. The average Tobin's $q$ is less than 1 for the sample and period considered. The average age of the stock of trademarks is approximately five years. The average number of trademarks per bank and quarter is 136 and there is a significant degree of variation: the maximum is 674 while the minimum is just 7 trademarks. This could be due to the banks' size and reinforces the necessity of standardize this variable by the bank size. The average rating category is A (6.27). M\&A variable shows that on overage $0.43 \mathrm{M} \& \mathrm{~A}$ announcements took place by quarter and bank. Thus, on average every 2.33 quarters there was a M\&A announcement.

Table 1. Summary statistics

\begin{tabular}{lccccc}
\hline \multicolumn{1}{c}{ Variable [units] } & Mean & Std. dev. & Min & Max & N \\
\hline Tobin's q [ratio] & 0.23 & $(0.13)$ & 0.05 & 1.06 & 704 \\
\hline Age $_{\text {lived }}$ [days] & 2057 & $(660)$ & 453 & 3907 & 704 \\
\hline Age $_{\text {cancel }}$ [days] & 1585 & $(1173)$ & 31 & 6606 & 704 \\
\hline Diversification [number] & 2.69 & $(0.45)$ & 1.17 & 3.46 & 704 \\
\hline Size (Equity Book Value) [mill \$] & 18399 & $(25694)$ & 629.79 & 132771 & 704 \\
\hline Stock [number] & 136 & $(133)$ & 7 & 674 & 704 \\
\hline Employees [number] & 56057 & $(63950)$ & 3988 & 328362 & 704 \\
\hline e-Commerce [mill \$] & 1.82 & $(0.73)$ & 0.70 & 3.40 & 464 \\
\hline Rating [1 lowest rating; 9 highest rating] & 6.27 & $(1.65)$ & 1 & 9 & 704 \\
\hline M\&A [number of announcements] & 0.43 & $(0.79)$ & 0 & 5 & 704 \\
\hline ROI [ratio] & 7.89 & $(3.55)$ & -0.226 & 30.737 & 672 \\
\hline
\end{tabular}


Next, we check the variables statistical properties analyzing the stationarity of the variables employed in our analysis to guess whether we must use the variable of interest (Tobin's $q$ ) in levels or first differences. We perform a standard Augmented DickeyFuller unit-root test using drift and/or trend when their effects are significantly different from zero at a 5\% significance level on the Tobin's $q$ variable for each bank. We find for all the banks in our sample that the dependent variable is stationary and thus, we use this variable in levels given that there should not be problems of cointegration with the explanatory variables. With the exception of the correlation between the Stock of trademarks and squared of the Stock of trademarks, which by definition is high (0.96), all the correlations among the remaining explanatory variables are always below 0.6. This level does not alert about potential problems of collinearity.

\section{Linear model}

The first empirical study analyzes the effect of trademark activity on bank performance in a classical Tobin's $q$ linear model. Thus, Tobin's $q$ provides the measure of performance, and the analysis refers to the bank level. Using the definition of Tobin's $q$ from Equation (2), this paper analyzes whether the added value in the market can be explained by the bank's particular management of its trademark activity. The linear regression model has the following form:

$$
\hat{q}_{i}=\alpha+\beta \frac{K_{i}}{A_{i}}
$$

The proxy for the value of innovation $K_{i}$ or intangible assets, is the number of each firm's living trademarks in quarter t, or Stock ${ }_{i t}$. By including the other variables of theoretical interest and the control variables, the following econometric model for each firm $i$ and each quarter $t$ arises:

$$
\frac{V_{i t}}{A_{i t}}=\alpha_{0}+\alpha_{1} \text { Stock }_{i t}+\alpha_{2} \text { Stock }_{i t}^{2}+\alpha_{3} \log \left(\overline{\text { Age }_{\text {lived }}}\right)_{i t}+\alpha_{4} \log \left(\overline{\text { Age }_{\text {cancel }}}\right)_{i t}+\gamma X_{i t}+\varepsilon_{i t} \text {, }
$$

where $\alpha_{0}$ is the intercept; $\alpha_{j}, j=1,2,3,4$, are the coefficients of the explanatory variables of theoretical interest (i.e. stock and age of the trademark portfolio); and $X_{i t}$ is a vector whose components are the control variables (i.e. lagged Tobin's $q$, Size, Diversification, e-commerce, lagged ROI, bank's rating, and M\&A). To estimate the coefficients, this study employs a Prais-Winsten regression with correlated panels, corrected standard errors (PCSEs) and robust to heteroskedasticity and contemporaneous correlation across panels. Under this methodology, each element in the covariance matrix of the disturbances is computed with all available observations that are common to the two panels contributing to the covariance. Due to the nature of the sample and to the similarities in the banks behavior on a given date, it seems important to consider any cross-sectional correlation effect across the 16 banks. We have also checked for the existence of first-order autocorrelation AR(1) in the residuals but we do not find the residuals to be auto-correlated.

\subsubsection{Trademark policy and abnormal returns: a classical event study}

In a second approach, this study examines the effect of banks' trademark policy according to a more dynamic performance measure, namely, abnormal returns. This classical 
event study, instead of using quarterly data, employs daily data and thus emphasizes a short-term perspective.

Event study methodology (e.g., Campbell et al. 1997) can analyze the impact of certain events on the stock returns of a firm or set of firms. This paper employs this methodology to study the effects of trademark introductions or cancellations on the abnormal returns of commercial banks; thus, this study can establish a link between managerial actions and the market value of a firm. This paper defines two types of events: the introduction of a new trademark and the cancellation or extinction of an old one. To estimate their effects, we also need to measure the expected returns in the case of no event, which requires a financial model for expected returns. In event studies of this type, the difference between the expected returns and the actual returns are the abnormal returns, denoted by $A R$. This work uses Fama and French's (1993) model to assess the firms' returns but also employs other specifications for the returns, such as an autoregressive model of order two, and obtains similar results.

The efficient market hypothesis predicts that in their trading decisions, investors incorporate all potential benefits of organizational initiatives announced by firms. If certain events, related to trademark activity, are likely to increase (diminish) a firm's future cash flows, the stock market should respond positively (negatively), and the firm's market value should change.

This estimation uses previous one-year data to estimate the abnormal returns for the data set of 16 banks. That is, abnormal returns for each day of the sample period are given by,

$$
A R_{i, t}=r_{i, t}^{\text {actual }}-\hat{r}_{i, t}^{\text {Fama-French }},
$$

where $A R_{i, t}$ denotes the abnormal returns at time $t$ for a bank $i$, which equals the difference between the returns at time $t\left(r_{i, t}^{a c t u a l}\right)$ and the expected returns according to the Fama-French model $\left(\hat{r}_{i, t}^{\text {Fama-French }}\right)$. Because $A R$ must be aggregated to draw overall conclusions about the event of interest, as well as to add robustness to the measure, the cumulative abnormal return, denoted by $C A R$, are computed for an interval around the event day,

$$
C A R_{i, t}=\sum_{j=-\tau}^{\tau} A R_{i, j},
$$

where $\tau$ is the number of days before and after the event, equal to $2 \tau+1$, for a bank $i$. This aggregation occurs over time and across banks which leads to an average CAR for each event and for a certain event window.

According to the null hypothesis, the $A R$ s are expected to be 0 . To check this hypothesis this study conducts a test based on the $J$ statistic. The $J$ statistic follows a $t$-distribution with $N-1$ degrees of freedom and allows testing the impact of trademark activity on abnormal returns:

$$
J=\frac{\overline{C A R}}{\operatorname{var}(\overline{C A R})} \propto t_{N-1},
$$

where $N$ is the length of the sample, and $\overline{C A R}$ is the average $C A R$ across all firms.

In the next section, we proceed to present the results for both analysis, the linear model for Tobin's $q$ and the event study with daily abnormal returns. 


\section{Empirical results}

\subsection{Linear model for Tobin's $q$}

The first empirical study defined in section 3.2.1 analyzes the effect of trademark activity on bank performance in a classical Tobin's $q$ linear model. Thus, we present here the estimation of the linear regression model of equation (4) in section 3.2.1., considering any cross-sectional correlation effect across the 16 banks.

Table 2 provides the estimation results of the model in Equation (4). In this table, each column shows the estimated coefficient, its degree of significance, and the corresponding standard errors in parenthesis.

Table 2. Prais-Winsten estimation of the linear model for Tobin's $q$.

\begin{tabular}{|c|c|c|c|c|}
\hline Variable & $\begin{array}{l}\text { Model } 1 \\
\text { (Std. Err.) }\end{array}$ & $\begin{array}{c}\text { Model } 2 \\
\text { (Std. Err.) }\end{array}$ & $\begin{array}{l}\text { Model } 3 \\
\text { (Std. Err.) }\end{array}$ & $\begin{array}{l}\text { Model } 4 \\
\text { (Std. Err.) }\end{array}$ \\
\hline $\log \left(\right.$ Age $\left._{\text {lived }}\right)$ & & $\begin{array}{c}-0.022^{* *} \\
(0.01)\end{array}$ & & $\begin{array}{c}-0.024^{* *} \\
(0.01)\end{array}$ \\
\hline $\log \left(\right.$ Age $\left._{\text {cancel }}\right)$ & & & $\begin{array}{c}0.001^{* *} \\
(0.00)\end{array}$ & $\begin{array}{c}0.001^{* *} \\
(0.00)\end{array}$ \\
\hline Stock & $\begin{array}{c}-7.269^{* *} \\
(3.45)\end{array}$ & $\begin{array}{c}-8.712^{* *} \\
(3.78)\end{array}$ & $\begin{array}{c}-8.658^{* *} \\
(3.49)\end{array}$ & $\begin{array}{c}-10.417^{\text {*** }} \\
(3.84)\end{array}$ \\
\hline Stock $^{2}$ & $\begin{array}{l}427.071 \\
(309.10)\end{array}$ & $\begin{array}{l}527.075 \\
(329.72)\end{array}$ & $\begin{array}{l}508.153 \\
(308.83)\end{array}$ & $\begin{array}{l}627.764^{*} \\
(330.53)\end{array}$ \\
\hline Tobin's $\mathrm{q}_{t-1}$ & $\begin{array}{c}0.846^{* * *} \\
(0.03)\end{array}$ & $\begin{array}{c}0.828^{* * *} \\
(0.04)\end{array}$ & $\begin{array}{c}0.845^{\text {*** }} \\
(0.03)\end{array}$ & $\begin{array}{c}0.825^{* * *} \\
(0.04)\end{array}$ \\
\hline Disversification & $\begin{array}{c}-0.033^{* * *} \\
(0.01)\end{array}$ & $\begin{array}{c}-0.035^{* * *} \\
(0.01)\end{array}$ & $\begin{array}{c}-0.034^{* * *} \\
(0.01)\end{array}$ & $\begin{array}{c}-0.035^{* * *} \\
(0.01)\end{array}$ \\
\hline Size & $\begin{array}{c}-0.009^{* * *} \\
(0.00)\end{array}$ & $\begin{array}{c}-0.008^{* * *} \\
(0.00)\end{array}$ & $\begin{array}{c}-0.010^{* * *} \\
(0.00)\end{array}$ & $\begin{array}{c}-0.009^{* * *} \\
(0.00)\end{array}$ \\
\hline e-Commerce & $\begin{array}{c}0.008^{* * *} \\
(0.00)\end{array}$ & $\begin{array}{c}0.010^{* * *} \\
(0.00)\end{array}$ & $\begin{array}{c}0.007^{* * *} \\
(0.00)\end{array}$ & $\begin{array}{c}0.009^{* * *} \\
(0.00)\end{array}$ \\
\hline$R O I_{t-2}$ & $\begin{array}{l}0.001^{*} \\
(0.00)\end{array}$ & $\begin{array}{l}0.001 \\
(0.00)\end{array}$ & $\begin{array}{l}0.001^{*} \\
(0.00)\end{array}$ & $\begin{array}{l}0.001^{*} \\
(0.00)\end{array}$ \\
\hline M\&A Announced & $\begin{array}{c}-0.0006 \\
(0.00)\end{array}$ & $\begin{array}{c}-0.0001 \\
(0.00)\end{array}$ & $\begin{array}{c}-0.0005 \\
(0.00)\end{array}$ & $\begin{array}{c}-0.00002 \\
(0.00)\end{array}$ \\
\hline Rating & $\begin{array}{c}-0.002 \\
(0.00)\end{array}$ & $\begin{array}{c}-0.0003 \\
(0.00)\end{array}$ & $\begin{array}{c}-0.002 \\
(0.00)\end{array}$ & $\begin{array}{c}-0.0001 \\
(0.00)\end{array}$ \\
\hline Intercept & $\begin{array}{c}0.216^{* * *} \\
(0.05)\end{array}$ & $\begin{array}{c}0.374^{* * *} \\
(0.10)\end{array}$ & $\begin{array}{c}0.226^{* * *} \\
(0.05)\end{array}$ & $\begin{array}{c}0.398^{* * *} \\
(0.10)\end{array}$ \\
\hline$R^{2}$ & 0.893 & 0.894 & 0.894 & 0.895 \\
\hline Wald Chi2 & 1850 & 1838 & 1861 & 1852 \\
\hline Prob Chi2 & 0 & 0 & 0 & 0 \\
\hline
\end{tabular}

Note: ${ }^{* * *}$ Significant at $1 \% .{ }^{* *}$ Significant at $5 \%$. ${ }^{*}$ Significant at $10 \%$ 
Model (1) in Table 2 represents the baseline model, with just the measure of trademark diversification (range of the stock of living trademarks) in each quarter across the three independent variables. The coefficient for this variable is negative and significant at a $1 \%$ level. Therefore, the ratio of market value to assets is lower when the diversification of the trademark portfolio increases. The coefficients of Stock and Stock ${ }^{2}$ show a convex form being the minimum at the value in which Stock is equal to 0.0085 . This suggests the existence of an optimal level of trademark activity such that an increase in the stock of trademarks below this level (0.0085) affects negatively to the bank performance but increases above this level improve bank performance. The banks that are above this threshold in any period of the sample are: Capital One Financial Corp., Keycorp, State Street Corp., U.S. Bancorp.

Model (2) includes the age of living trademarks to investigate if an older stock implies a lower Tobin's $q$. The coefficient is negative and significant at $5 \%$, which supports the claim that an older portfolio of trademarks diminishes the ratio of market value to assets. A relatively younger stock of living trademarks thus is beneficial. The coefficient and sign estimated for the diversification variable match those obtained in Model (1), which reinforces the notion that specific trademarks add more value to the firm.

Model (3) includes the average age of cancelled trademarks, to test whether the best strategy for gaining market value through trademarks is to eliminate old trademarks from portfolios. Using the same baseline, namely, the controls from Models (1) and (2), the results indicate that the coefficient of $\log \left(\overline{\text { Age }_{\text {cancel }}}\right)$ is positive and significant at $5 \%$. Thus, these results show support for the proposition that not only should the stock of living trademarks be young, but cancelled trademarks should be the oldest in the portfolio to improve Tobin's $q$.

Finally, Model (4) includes all the proposed variables at the same time. The results for the control variables do not vary significantly, nor do the coefficients and signs for the variables of interest differ materially from those obtained by using the variables separately in Models (1), (2), and (3). Specifically, the estimation results of control variable coefficients are quite robust in all model specifications: the lagged Tobin's $q$ coefficient is positive and very significant, whereas the size coefficient is negative and significant at the $1 \%$ level. As in Model (1), the stock per employee and its squared show a convex form. The e-commerce variable, which represents a common trend for all banks, displays a positive and significant effect on Tobin's $q$ at $1 \%$ significance level. Finally, $R O I_{t-2}$, or firm performance in the two preceding periods, has positive coefficients in all specifications and a significance of $10 \%$. These results indicate a positive relationship between past performance and the ratio of current market value to assets. The rating and M\&A are not significant in any of the four specifications at any standard level of significance.

Innovation and strategy management literature indicates an important role of product portfolio diversification, so this study also considered several diversification control variables, such as the Herfindahl index. In particular, the Herfindahl index of concentration for the type of trademark according to its international class is taken into account in this study. If this index equals one, all trademarks in that quarter belong to the same international class (the most common class in the sample is insurance and financial ser- 
vices, $\mathrm{IC}=36$ ). However, none of the diversification control variables was significant. In an alternative specification of the model, the estimation controls for the effect of systematic risk in Tobin's $q$ using the quarterly fundamental beta, or the measure of the sensitivity of the bank's stock price to overall fluctuations in Standard \& Poor's 500. The beta equals the difference between the realized beta for a given bank and the beta associated with the market portfolio, equal to one, in absolute value which penalizes superior and inferior deviations in the same grade. However, this analysis does not include this measure of systematic risk in the final results because of its collinearity with the other control variables.

According to the overall results, there is an optimal level of trademark activity such that an increase in the stock of trademarks below this level affects negatively to the bank performance but increases above this level improve bank performance. This optimal level of trademarks should be reached with new focused trademarks and should be accompanied by the cancellation of old and non-focused trademarks. It should also be noted that Tobin's $q$ offers a long-term perspective, whereas firms act in response to short-term market reactions. For this reason, we next do a short-term analysis of the effect of trademark activity on banks returns.

\subsection{Event study}

Now, we present the results related with the effects of banks' trademark policy from a short-term perspective. For that purpose, we examine the CARs and their significance defined in equations (6) and (7) of section 3.2.2. The sample consists of 960 cancellations and 1560 introductions by the 16 commercial banks over the 11-year period.

Figure 1 reports the CARs for different event windows and three cases: days with an introduction (dashed line), days with a cancellation (dotted line), and days with no events (solid line). The event windows for Figures 1A, 1B, 1C, and 1D are, respectively, $(-14,+14)$ days, $(-7,+7)$ days, $(-5,+5)$ days, and $(-3,+3)$ days. The results show that an introduction has a positive effect compared with no event on the $C A R$. However, a cancellation event has a negative impact on the CAR.

Table 3 presents these statistics for different event windows, ranging from 1-14 days before to 1-14 days after the event. In Table 3, the variable $C A R_{\text {intro }}$ denotes the cumulative abnormal returns for days with an introduction, while the variable $C A R_{\text {cancel }}$ denotes the cumulative abnormal returns corresponding to days with a cancellation. The variable $C A R_{\text {no event }}$ represents the cumulative abnormal returns for days with no events. In Table 3, the adjacent columns for each $C A R$ indicate the corresponding $J$ statistics.

Trademark activity has significant impacts on the $A R \mathrm{~s}$ in the sample. A trademark introduction exerts a positive impact compared with no event in the CARs, though CARs are significant only at $10 \%$ for the $(-14,+14)$ day window. For example, for this window, the mean CARs to trademarks introduction is approximately $7 \%$, whereas the no event $C A R$ is $-5 \%$. For a trademark cancellation, the $J$ statistics are all negative and significant; in particular, the CARs for the $(-3,+3),(-5,+5),(-7,+7)$, and $(-14,+14)$ day windows, are approximately $-5 \%(p<0.10),-10 \%(p<0.01),-15 \%(p<0.01)$, and $-14 \%(p<0.01)$, respectively. 
Fig. 1A. Event window $(-14,14)$ days

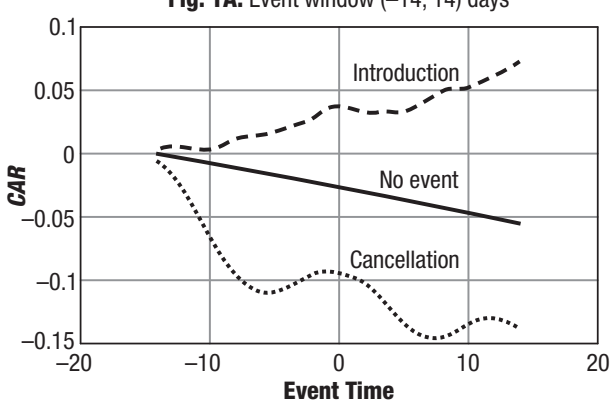

Fig. 1C. Event window $(-5,5)$ days

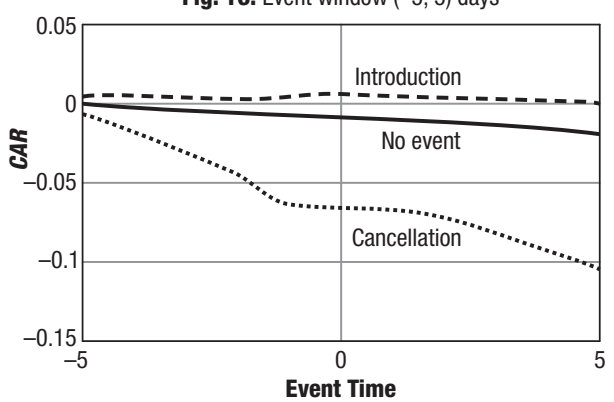

Fig. 1B. Event window $(-7,7)$ days

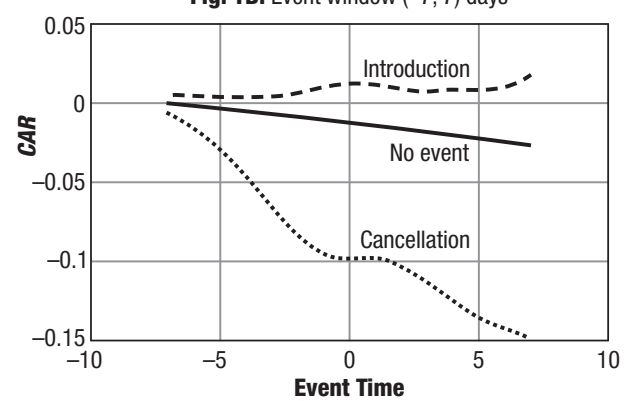

Fig. 1D. Event window $(-3,3)$ days

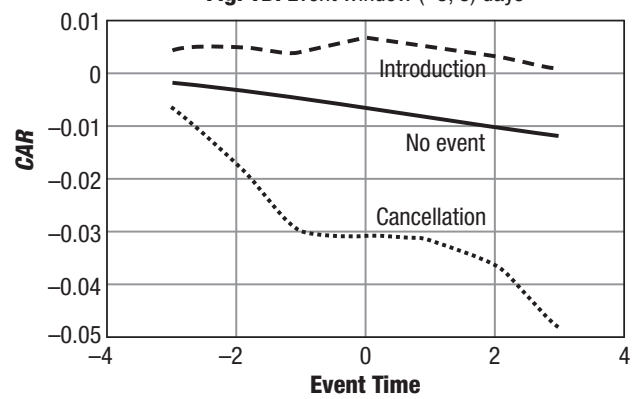

Fig. 1. $C A R$ evolution versus event time for different windows

Table 3. Averaged $C A R$ statistics for trademark introduction and cancellation with different event windows

\begin{tabular}{ccccccc}
\hline Window & CAR intro & J-stat & CAR cancel & J-stat & CAR no event & J-stat \\
\hline-1 to +1 & 0.006 & 0.43 & -0.008 & -0.49 & $-0.006^{*}$ & -1.87 \\
\hline-3 to +3 & 0.001 & 0.04 & $-0.049^{*}$ & -1.94 & $-0.012^{* * *}$ & -2.59 \\
\hline-5 to +5 & 0.001 & 0.02 & $-0.104^{* * *}$ & -3.26 & $-0.019^{* * *}$ & -3.14 \\
\hline-7 to +7 & 0.017 & 0.59 & $-0.149^{* * *}$ & -3.92 & $-0.026^{* * *}$ & -3.78 \\
\hline-14 to +14 & $0.071^{*}$ & 1.73 & $-0.138^{* * *}$ & -2.59 & $-0.055^{* * *}$ & -5.79 \\
\hline
\end{tabular}

Note: ${ }^{* * *}$ Significant at $1 \% .{ }^{* *}$ Significant at $5 \%$. ${ }^{*}$ Significant at $10 \%$

As we have already mentioned, this sample represents a period with a strong activity of mergers and acquisitions in the banking sector. Therefore, as a robustness test and to avoid any trends in the data that could be confused with abnormal returns, we filter the first 20 trading days from the announcement of a merger or acquisition, and then carry out the event study described above. Now, the CARs observed for the trademark activity taking into account mergers and acquisitions are presented in Table 4. The plots in Figure 2 represent the mean $C A R s$ to banks introducing and cancelling trademarks on each of the days in the 5-day and 7-day windows. 
Table 4. Averaged $C A R$ statistics for trademark introduction and cancellation with different event windows filtering by M\&A announcements

\begin{tabular}{ccccccc}
\hline Window & $C A R$ intro & J-stat & $C A R$ cancel & J-stat & $C A R$ no event & J-stat \\
\hline-1 to +1 & 0.019 & 1.34 & 0.001 & 0.06 & $-0.006^{* *}$ & -2.12 \\
\hline-3 to +3 & 0.029 & 1.39 & -0.026 & -0.96 & $-0.014^{* * *}$ & -2.99 \\
\hline-5 to +5 & $0.045^{*}$ & 1.68 & $-0.070^{* *}$ & -2.04 & $-0.021^{* * *}$ & -3.64 \\
\hline-7 to +7 & $0.081^{* * *}$ & 2.60 & $-0.101^{* * *}$ & -2.48 & $-0.030^{* * *}$ & -4.38 \\
\hline-14 to +14 & $0.211^{* * *}$ & 4.82 & -0.058 & -1.01 & $-0.063^{* * *}$ & -6.66 \\
\hline
\end{tabular}

Note: ${ }^{* * *}$ Significant at $1 \%$. ${ }^{* *}$ Significant at $5 \%$. ${ }^{*}$ Significant at $10 \%$

Fig. 2A. Event window $(-7,7)$ days

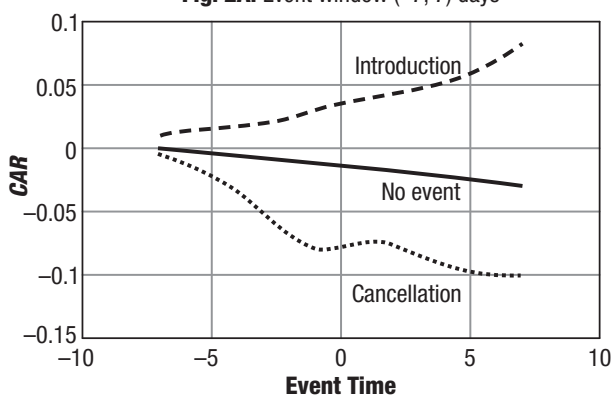

Fig. 2B. Event window $(-5,5)$ days

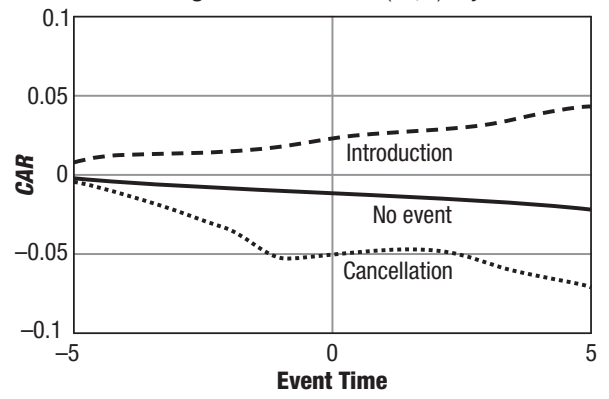

Fig. 2. $C A R$ evolution versus event time filtering by M\&A information

The results shown in Table 4 and Figure 2 indicate that the CARs to trademarks introduction are positive and significant for event windows of $(-5,+5),(-7,+7)$, and $(-14$, $+14)$ days; having CARs equal to $4.5 \%(p<0.10), 8.1 \%(p<0.01)$ and $21.1 \%(p<$ $0.01)$, respectively. In contrast, the $C A R s$ for those banks that cancelled a trademark are negative and significant at the end of the 5-day window around the cancellation $(C A R s=$ $7 \%$, with $p<0.05)$, as well as at the end of the 7-day event window (CARs $=10.1 \%$, with $p<0.01)$. Hence, this robustness test confirms the validity of the previous results. Thus, the ARs attributable to the creation of a trademark are different from those attributable to a cancellation. The performance measures in Sections 4.1 and 4.2 differ in both conceptual and temporal features. The conceptual difference is obvious; regarding the temporal dimension, Section 4.1 is based on quarterly data, whereas Section 4.2 uses daily data. Therefore, some firm actions might not be perceived as advantageous for bank performance in the short run but would benefit firm value in the long run, perhaps due to long-term intra-firm synergies.

The overall results suggest that a new trademark generates positive abnormal returns, which gives marketing managers incentives to file new trademarks. Cancelling a trademark generates negative abnormal returns; from a short-term perspective, a cancellation does not seem like a good strategy. Yet such a strategy would lead to excessive trademarks, based solely on short-term incentives. Even though the cancellation of trade- 
marks leads to negative and significant abnormal returns in the short term, the results in Section 4.1 indicate that when controlling for age and other potential control variable, cancellations can lead to positive long-run effects on firm value, especially if they help focus the scope of the trademark portfolio.

\section{Conclusions}

Advertising plays an important role for commercial banks and their profitability (Örs 2006). At the same time, advertising is closely linked to the possession of a relevant portfolio of trademarks. Because of the close relationship between trademarks and advertising, trademark activity should have a key influence on commercial banking. Following this line of reasoning, this empirical study tries to shed light on the relationship among trademark activity, market value, and firm performance.

This paper analyzes and measures empirically the effects of intangible assets, in the form of trademark activity, on the market value and the stock performance of commercial banks in the United States-one of the most innovative industries in modern economies. When Tobin's $q$ is the dependent variable, results show that the ratio of market value to assets is lower when the diversification in the trademark portfolio increases. In addition, the coefficient for the age of the trademarks is negative and significant. Therefore, maintaining a relatively young stock of trademarks seems to be beneficial. To improve the Tobin's $q$, firms can also ensure that the trademarks they cancel are the oldest ones in their portfolio. Using abnormal returns on a daily basis, the results indicate a positive (negative) abnormal return around the date of the introduction (cancellation) of a trademark. Latter results are robust to including information of mergers and acquisitions dates.

These results thus have key implications for both investors and bank managers. An investor can infer, from a bank's trademark policy, the value of the firm. For example, if a bank cancels its divergent, old trademarks, investors should predict positive long-run effects on the bank's value. Thus, among many other economic indicators, investors should attend to the bank's trademark policy to determine their investment strategy, depending on their time horizon.

Bank managers also might use these results to guide decisions about managing the trademark portfolio more efficiently and with lower expenditures. In the short run, the market perceives trademark introductions positively, leading to significant positive abnormal returns. Efficient portfolio management requires that the trademark activity is above the optimal level which guarantees that increases in the stock of trademarks above this level improve bank performance. This optimal level should be reached with new focused trademarks and should be accompanied by the cancellation of old and nonfocused trademarks. Such cancellations not only improve performance but also imply savings for the bank, because it is costly to maintain trademarks.

Among others, Lin et al. (2006) claim that the most challenging task of today's managers in the knowledge-based economy is to exploit the full value of corporate knowledge assets and to accumulate and commercialize knowledge assets effectively. Rutkauskas 
and Ginevicus (2011) also show the relevance for modern organizations of an integrated analysis of marketing efficiency and risks. This paper here agrees with both statements. The current economic environment reinforces the importance and usefulness of new technologies, as well as the diminishing appropriateness of old products due to the emergence of new habits and behaviors. The bank sector is not an outside spectator of these changes; rather, this sector has become one of the most innovative industries. Consider an interesting question for further research. What is the optimal timing for cancelling trademarks? The results suggest that old, diversified trademarks must be cancelled, but there could be a positive relation between a stable, nonvolatile economic scenario and trademark cancellation. This timing could reflect a lesser impact in the short run but significant effects on long-run bank performance.

\section{Acknowledgements}

The authors thank Marco Giarratana, Andrea Fosfuri, Ieva Meidute (the editor), and the referees for their helpful comments and suggestions. The usual disclaimer applies.

\section{References}

Agrawal, J. W.; Kamamura, W. A. 1995. The economic worth of celebrity endorsers: an event study analysis, Journal of Marketing 59: 56-62. http://dx.doi.org/10.2307/1252119

Bayus, B. L.; Erickson, G.; Jacobson, R. 2003. The financial rewards of new product introductions in the personal computer industry, Management Science 49(2): 197-210.

http://dx.doi.org/10.1287/mnsc.49.2.197.12741

Bharadwaj, A. S.; Bharadwaj, S. G.; Konsynski, B. R. 1999. Information technology effects on firm performance as measured by Tobin's q, Management Science 45(7): 1008-1024.

http://dx.doi.org/10.1287/mnsc.45.7.1008

Branch, B. 1974. Research and development activity and profitability: a distributed lag analysis, Journal of Political Economy 82: 999-1011. http://dx.doi.org/10.1086/260252

Campbell, J. Y.; Lo, A. W.; MacKinlay, A. C. 1997. The Econometrics of Financial Markets. Princeton University Press. Princeton, New Jersey.

Chaney, P. K.; Devinney, T. M.; Winer, R. S. 1991. The impact of new product introduction on the market value, Journal of Business 64(4): 573-611. http://dx.doi.org/10.1086/296552

Fama, E.; French, K. 1993. Common risk factors in the return of stocks and bonds, Journal of Financial Economics 33: 3-56. http://dx.doi.org/10.1016/0304-405X(93)90023-5

Fosfuri, A.; Giarratana, M. 2009. Masters of war: rivals' product innovation and new advertising in mature product markets, Management Science 55(2): 181-191.

http://dx.doi.org/10.1287/mnsc.1080.0939

Gambardella, A.; Torrisi, S. 1998. Does technological convergence imply convergence in markets? Evidence from the electronics industry, Research Policy 27: 445-463.

http://dx.doi.org/10.1016/S0048-7333(98)00062-6

Grabowski, H. G.; Mueller, D. C. 1978. Industrial research and development, intangible capital stocks, and firm profit rates, Bell Journal of Economics 9(2): 328-343.

http://dx.doi.org/10.2307/3003585

Greenhalgh, C.; Rogers, M. 2007. Trade marks and performance in UK firms: evidence of Schumpeterian competition through innovation, Oxford Intellectual Property Research Center, Working Paper. 
Grilliches, Z. 1981. Market value, R\&D, and patents, Economics Letters 7(2): 183-187.

Hall, B. H. 1993. The stock market's valuation of R\&D investment during the 1980's, AEA Papers and Proceedings 70(2): 259-264.

Hall, B. H.; Thoma, G.; Torrisi, S. 2007. The market value of patents and R\&D: evidence from European firms, NBER Working Paper.

Hasan, I.; Hunter, W. C.; Mathis III, R. E. 2000. Promotional expenditures, market competition, and thrift behavior, Journal of Business Research 50: 177-184.

http://dx.doi.org/10.1016/S0148-2963(99)00030-2

Hozier, G. C.; Schatzber, J. D. 2000. Advertising agency terminations and reviews: stock returns and firm performance, Journal of Business Research 50: 169-176.

http://dx.doi.org/10.1016/S0148-2963(99)00029-6

Koh, J.; Venkatraman, N. 1991. Joint venture formations and stock market reactions: an assessment in the information technology sector, Academy of Management Journal 34(4): 869-892. http://dx.doi.org/10.2307/256393

Krasnikov, A.; Mishra, S.; Orozco, D. 2009. Evaluating the financial impact of branding using trademarks: a framework and empirical evidence, Journal of Marketing 73(4): 154-166.

http://dx.doi.org/10.1509/jmkg.73.6.154

Lane, V.; Jacobson, R. 1995. Stock market reactions to brand extension announcements: the effects of brand attitude and familiarity, Journal of Marketing 59(1): 63-77.

http://dx.doi.org/10.2307/1252015

Li, D.; Jin, J. 2006. The effect of diversification on firms returns in chemical and oil industries, Review of Accounting and Finance 5(1): 20-29. http://dx.doi.org/10.1108/14757700610646916

Lin, B.-W.; Lee, Y.; Hung, S.-C. 2006. R\&D intensity and commercialization orientation effects on financial performance, Journal of Business Research 59: 679-685.

http://dx.doi.org/10.1016/j.jbusres.2006.01.002

Lindenberg, E. B.; Ross, S. A. 1981. Tobin's q ratio and industrial organization, Journal of Business 54(1): 1-32. http://dx.doi.org/10.1086/296120

Lubatkin, M. 1983. Mergers and the performance of the acquiring firms, Academy of Management Review 8: 59-65.

Mathur, L. K.; Mathur, I. 1995. The effect of advertising slogan changes on the market values of firms, Journal of Avertising Research 35: 59-65.

Megna, P.; Klock, M. 1993. The impact of intangible capital on Tobin's q in the semiconductor industry, American Economic Review 83(2): 265-269.

Örs, E. 2006. The role of advertising in commercial banking, CEPR Discussion Paper No. 5461.

Reilly, F. K.; McGann, A. F.; Marquardt, R. A. 1997. Advertising decisions and stockholders' wealth, Journal of Advertising Research 17: 49-56.

Rindova, V. P.; Petkova, A. P. 2007. When is a new thing a good thing? Technological change, product form design, and perceptions of value for product innovations, Organization Science 18(2): 217-232. http://dx.doi.org/10.1287/orsc.1060.0233

Rutkauskas, A. V.; Ginevicius, A. 2011. Integrated management of marketing risk and efficiency, Journal of Business Economics and Management 12(1): 1-23.

http://dx.doi.org/10.3846/16111699.2011.555357

Salas, V.; Saurina, J. 2003. Deregulation, market power and risk behavior in Spanish banks, European Economic Review 47: 1061-1075. http://dx.doi.org/10.1016/S0014-2921(02)00230-1

Seethamraju, C. 2003. The value relevance of trademarks, in Hand, J. R. M.; Lev, B. (Eds.). Intangible Assets: Values, Measures, and Risks. Oxford University Press, Oxford, United Kingdom. 
Siggelkow, N. 2003. Why focus? A study of intra-industry focus effects, Journal of Industrial Economics 51(2): 121-150. http://dx.doi.org/10.1111/1467-6451.00195

Simon, C. J.; Sullivan, M. W. 1993. The measurement and determinants of brand equity: a financial approach, Marketing Science 12(4): 28-52. http://dx.doi.org/10.1287/mksc.12.1.28

Srinivasan, S.; Pauwels, K.; Silva-Risso, J.; Hanssens, D. M. 2009. Product innovations, advertising, and stock returns, Journal of Marketing 73(1): 24-43. http://dx.doi.org/10.1509/jmkg.73.1.24 Sorenson, O. 2000. Letting the market work for you: an evolutionary perspective on product strategy, Strategy Management Journal 21: 577-592.

http://dx.doi.org/10.1002/(SICI)1097-0266(200005)21:5<577::AID-SMJ105>3.0.CO;2-C

Teece, D. J. 1986. Profiting from technological innovation: implications for integration, collaboration, licensing and public policy, Research Policy 15: 21-45.

http://dx.doi.org/10.1016/0048-7333(86)90027-2

Tobin, J. 1978. Monetary policies and the economy: the transmission mechanism, Southern Economic Journal 37: 421-431. http://dx.doi.org/10.2307/1057201

Wernerfelt, B.; Montgomery, C. A. 1988. Tobin's q and the importance of focus in firm performance, American Economic Review 78(1): 246-250.

Carlos GONZÁLEZ-PEDRAZ. Teaching Assistant and PhD candidate at the Department of Business Economics, Universidad Carlos III de Madrid, Spain. He received a M.S. in Quantitative Finance from Universidad Complutense de Madrid. His research interests include asset pricing and risk management.

Sergio MAYORDOMO. He received a M.S. degree in Finance and Economics from CEMFI and a $\mathrm{PhD}$ in Finance from Universidad Carlos III de Madrid. He has held teaching positions at Universidad Carlos III and ESCP Business School. His research interests include security analysis, financial econometrics, and asset pricing. 